\title{
The Evolution of Mindfulness-Based Physical Interventions in Breast Cancer Survivors
}

\author{
Daniela L. Stan, ${ }^{1}$ Nerissa M. Collins, ${ }^{1}$ Molly M. Olsen, ${ }^{1}$ Ivana Croghan, ${ }^{2}$ and Sandhya Pruthi ${ }^{1}$ \\ ${ }^{1}$ Department of General Internal Medicine, Mayo Clinic, 200 First Street SW, Rochester, MN 55905, USA \\ ${ }^{2}$ Nicotine Research Program, Primary Care Internal Medicine, Mayo Clinic, 200 First Street SW, Rochester, MN 55905, USA
}

Correspondence should be addressed to Daniela L. Stan, stan.daniela@mayo.edu

Received 8 May 2012; Accepted 27 June 2012

Academic Editor: Andreas Michalsen

Copyright ( 2012 Daniela L. Stan et al. This is an open access article distributed under the Creative Commons Attribution License, which permits unrestricted use, distribution, and reproduction in any medium, provided the original work is properly cited.

\begin{abstract}
Survivors of breast cancer are faced with a multitude of medical and psychological impairments during and after treatment and throughout their lifespan. Physical exercise has been shown to improve survival and recurrence in this population. Mind-body interventions combine a light-moderate intensity physical exercise with mindfulness, thus having the potential to improve both physical and psychological sequelae of breast cancer treatments. We conducted a review of mindfulness-based physical exercise interventions which included yoga, tai chi chuan, Pilates, and qigong, in breast cancer survivors. Among the mindfulness-based interventions, yoga was significantly more studied in this population as compared to tai chi chuan, Pilates, and qigong. The participants and the outcomes of the majority of the studies reviewed were heterogeneous, and the population included was generally not selected for symptoms. Yoga was shown to improve fatigue in a few methodologically strong studies, providing reasonable evidence for benefit in this population. Improvements were also seen in sleep, anxiety, depression, distress, quality of life, and postchemotherapy nausea and vomiting in the yoga studies. Tai chi chuan, Pilates, and qigong were not studied sufficiently in breast cancer survivors in order to be implemented in clinical practice.
\end{abstract}

\section{Introduction}

Cancer survivorship, as a distinct and complex phase of the cancer journey, has gained strong support by both survivors of breast cancer and their clinicians. Breast cancer survivors account for 2.4 million of the 10 million cancer survivors in the United States [1].

Survivors of breast cancer are faced with a multitude of medical and psychological impairments during and after treatment and throughout their lifespan. One intervention shown convincingly to improve some of the long-term toxicities and late effects of therapy is physical exercise [2,3]. Moderate physical exercise has also been associated with reducing breast cancer risk among postmenopausal women [4]. Aerobic training has also been shown to increase recurrence-free and overall survival in this population [5]. Such conventional exercise regimens however can be challenging for women who have undergone surgery, chemotherapy, and/or radiation treatment who are also experiencing the additional burden of anxiety and stress about the possibility of recurrence.
Thus, it is not surprising that breast cancer survivors are increasingly exploring interventions that combine mind and body components, herein referred to as "mindful exercise." Mindful exercise includes yoga, tai chi chuan, Pilates, and qigong. These exercise interventions address both physical and psychological needs simultaneously and may be particularly appealing to breast cancer survivors [6]. A growing number of research studies in breast cancer survivors have demonstrated beneficial effects such as improving quality of life (QOL) and fitness levels while reducing fatigue and depression [7-10].

Published reviews of mindful exercise interventions lack the comprehensive inclusiveness that is part of the mindfulbased exercise modalities (yoga, tai chi chuan, Pilates, and qigong) but instead focus on only one method. These interventions are similar in their philosophy of affecting both the mind and the body, and they target similar outcomes of QOL, mood, and fatigue. In this paper, we provide a comprehensive review of the scientific evidence on the effect of all mindful exercise interventions in breast cancer survivors. 


\section{Background}

Heightened awareness of cancer survivorship issues in the late 1990s, coupled with evidence that most cancer survivors use one or more forms of complementary and alternative medicine (CAM) [11], led to an increased recognition of the need for rigorous research in this arena. The Office of Cancer Complementary and Alternative Medicine and the National Center for Complementary and Alternative Medicine, created within the National Cancer Institute, encourage and support the scientific scrutiny of CAM therapies for treatment of cancer and cancer sequelae. This growing body of research has led to a renaissance in how both patients and physicians address the wellness of the whole person, including the physical, psychological, and spiritual needs.

A high proportion of breast cancer survivors use one or more types of CAM, the most popular categories being the "natural products" and "mind-body practices" $[6,12,13]$. Mind-body practices target the "interaction between brain, mind, body, and behavior, with the intent to use the mind to affect the physical function and promote health" [14]. These practices include meditation, guided imagery, deepbreathing exercises, progressive relaxation, hypnotherapy, yoga, tai chi chuan, qigong, and acupuncture. Some of these methods are mostly meditative, while others such as yoga, tai chi chuan, and qigong include a significant physical component which qualifies them as distinct fitness methods. Another fitness method that is part of the "movement" category of CAM therapies is the Pilates method [14].

In the general population, yoga and Pilates are the fastest growing fitness methods [15]. These interventions are greatly advertised to breast cancer survivors as effective methods of rehabilitation, despite limited scientific evidence of their benefit on QOL and other psychological parameters. It has been claimed that the mindfulness component connects the body, mind, spirit, thus having beneficial effects on depression, anxiety, fatigue, and pain [16-18]. However, the majority of the research on mind-body interventions involves studies that are small and lack a proper comparison group [19-21].

Given the importance of physical activity in improving sequelae of breast cancer treatment and decreasing the recurrence and mortality rates, it is prudent that clinicians and researchers understand if physical exercise with a mindful component has similar effects. The purpose of our paper is to provide an overview of the scientific evidence of the effect of all mindful exercise interventions among breast cancer survivors.

\section{Yoga}

The most studied of the mindful exercise interventions, yoga, has origins in the Buddhist tradition about 5000 years ago. There are 13 types of yoga, some more meditative (Kundalini) and others more physical (Hatha and the styles derived from it: Iyengar, Ashtanga, and Vinyasa) [22], but they all involve the union between mind, body, and spirit.

The most practiced in the Western world today is Hatha yoga and its derivations. A survey conducted in 2007 by the
National Center for Complementary and Alternative Medicine on the use of CAM by Americans demonstrated that more than 13 million adults had used yoga in the previous year and that the use of yoga among adults increased by 3 million people between 2002 and 2007 . According to this survey, the most common reasons people use yoga for are its beneficial effects on anxiety, stress, asthma, high blood pressure, and depression, but yoga is also used as part of a general health regimen for physical fitness and relaxation [23].

Hatha yoga includes a vast array of asanas (postures done with awareness) and pranayama (regulated breathing through the nostrils), with the purpose of relaxing the body and quieting the thoughts $[18,19]$. Iyengar yoga focuses on alignment and holding poses, while the Ashtanga yoga features poses that flow together [22]. Scientific inquiries of yoga benefits started to occur in the early 1970s with reports of benefits in medical ailments such as hypertension, anxiety, depression, and back pain, to name a few. Over the last decade, the number of studies addressing Hatha yoga in cancer survivors has surged and their methodologic quality is improving.

\section{Tai Chi Chuan (TCC)}

Tai chi chuan is a multicomponent intervention that has its origins in China, as a martial art. It combines meditation, graceful movement, deep breathing, and relaxation to move vital energy throughout the body [49]. Over the past 20 years, TCC has been found to be successful at reducing falls and improving sleep in the elderly $[50,51]$, improving QOL and increasing exercise tolerance in heart failure patients $[49,52]$, improving physical functioning in patients with rheumatoid arthritis [53], improving blood pressure and cholesterol in hypertensive patients [8], and improving bone mineral density [54]. Recent methodologically stronger studies have brought TCC to the attention of the medical community by demonstrating significant improvements in symptoms and QOL in patients with fibromyalgia [55] and in the balance, functional capacity, and falls risk of patients with Parkinson's disease [56]. In cancer populations, tai chi chuan was studied mostly in breast cancer survivors.

\section{Pilates}

The Pilates method was developed by the German trainer Joseph Pilates in the 1930s. It combines exercises inspired from yoga, karate, Zen meditation, and the ancient Greek and Roman philosophies of achieving physical and mental perfection $[57,58]$. Pilates strengthens the core muscles which subsequently can lead to improvement in spine flexibility and posture [59]. Initially popular with professional dancers and later adopted by professional athletes, Pilates has become extremely popular in the general population. The practice of Pilates has increased by $450 \%$ since 2000 , with 8.6 million participants in 2009 [15]. The medical field also followed suit, with more than fifty peer-reviewed publications reporting beneficial effects from Pilates in 
health-related conditions such as back pain, orthopedic rehabilitation, fibromyalgia, and QOL in the elderly [60-63].

Pilates exercises are practiced on a floor mat, on a special Pilates chair, or with the help of a spring machine (the Pilates reformer). While performing the exercises, the awareness is on breathing and muscle control. Positive claims associated with Pilates include increased flexibility, range of motion (ROM), muscle endurance, cardiorespiratory fitness, mood level, motivation, energy level, and coordination. However, many of these claims are poorly supported with evidencebased studies [64].

\section{Qigong}

This is a form of Chinese health exercise and is an important part of Chinese traditional medicine, consisting of a combination of slow movements, self-massage, slow breathing, healing posture, and meditation $[7,18]$. It is the most commonly practiced form of mindful exercise used worldwide, having been practiced for over 3,000 years. Qigong has been studied intensively in medical conditions including depression, hypertension, cardiovascular disease, and anxiety. Studies of qigong in cancer survivors $(N=15$ studies $)$ have reported benefits in QOL, mood, fatigue, and inflammation [72].

\section{Methods}

Two independent reviewers performed a literature search of the Ovid databases (EMBASE and MEDLINE) from inception until February 2012 (in the title area) and the PubMed database (in the title/abstract area) for the following terms: "yoga AND breast cancer," "tai chi chuan AND breast cancer," "Pilates AND breast cancer," "qigong AND breast cancer", and "mindful exercise AND breast cancer." Included in this analysis were the following types of human studies: randomized controlled (RCT), nonrandomized controlled (CCT), one-arm pilot studies, and surveys. Excluded from the analysis were reviews (systematic and nonsystematic), case reports, case series, and conference abstracts.

One investigator (DLS) then assessed the results and excluded studies in which the mindful exercise intervention was not specifically targeted to cancer survivors and those that were obvious duplicates. The reference list of the studies included was evaluated for missed publications and then these were included in the study. Studies for which the outcomes were reported as two to four separate publications were combined in a single entry.

The articles that met the inclusion criteria were reviewed independently by two investigators and the relevant data were abstracted.

\section{Results}

Yoga. The search "yoga AND breast cancer" identified 42 publications, of which 25 met the inclusion criteria. These included 17 RCTs, 1 survey, and 7 one-arm pilot studies. Table 1 describes the study design, type of yoga studied, outcome measured, and results of these studies.
Tai Chi Chuan. The search "tai chi chuan AND breast cancer"identified 11 studies of TCC in breast cancer survivors, and 5 qualified for inclusion: 4 RCTs and 1 one-arm pilot study, as described in Table 2.

Pilates. The search "Pilates AND breast cancer" identified 3 studies addressing the effect of the Pilates exercises in breast cancer survivors. Two were included in this review (1 RCT and 1 one-arm pilot). These studies are described in Table 3.

Qigong. The search "qigong AND breast cancer" identified 5 studies of qigong in breast cancer survivors and 4 were included in the analysis: 1 RCT, 2 CCTs, and 1 one-arm pilot, as listed in Table 4.

\section{Discussion}

This comprehensive review reveals that yoga is the most studied of the mindful exercise interventions in breast cancer survivors, whereas TCC, Pilates, and qigong are less well represented.

Yoga. Historically, the first publication of the effects of yoga in breast cancer survivors appeared in 2003 [75]. In this study, yoga was part of a more comprehensive intervention named "Mindfulness-Based Stress Reduction" (MBSR) in a sample of breast cancer $(N=59)$ and prostate cancer $(N=10)$ survivors. There was evidence of increased QOL and sleep quality and decreased stress after the intervention, but without a control group, the findings are limited.

It was not until 2006, when a survey of 2022 survivors of any cancer in the Nurses Health Study [6] showed that 62\% of this population used one or more CAM methods, that the interest in yoga use in cancer survivorship increased. In this study, yoga was the only CAM intervention that increased the QOL compared to the nonusers of CAM. In fact, users of CAM methods other than yoga had a lower QOL compared to the nonusers in this study, a finding also seen in a previous study of general cancer survivors [76].

We identified 24 studies of yoga in breast cancer survivors. The outcomes assessed in these studies are heterogeneous, although some of them are a recurrent theme, such as fatigue ( 9 trials, 6 showing significantly favorable results), QOL (8 trials, all positive), anxiety (8 studies, all positive), and depression (9 studies, 8 positive). Other less common outcomes assessed were sleep ( 5 studies, 2 positive), stress, mood, mental health, affect, spirituality, vitality, distress, pain, physical fitness, cognition, chemo-induced nausea, and vomiting. Statistical significant or trends toward improvements were shown for all of these outcomes in the majority of the studies reviewed here. Notable negative results were found for weight, BMI, and hip circumference in a study of postmenopausal obese or overweight breast cancer survivors [28]. In this study, despite a slight weight gain, there was a significant decrease in the waist circumference of $-3.1 \mathrm{~cm}$ in the yoga versus control population.

The population selected for these studies was relatively heterogeneous with respect to stage of disease and time since breast cancer diagnosis. In addition, the participants were 


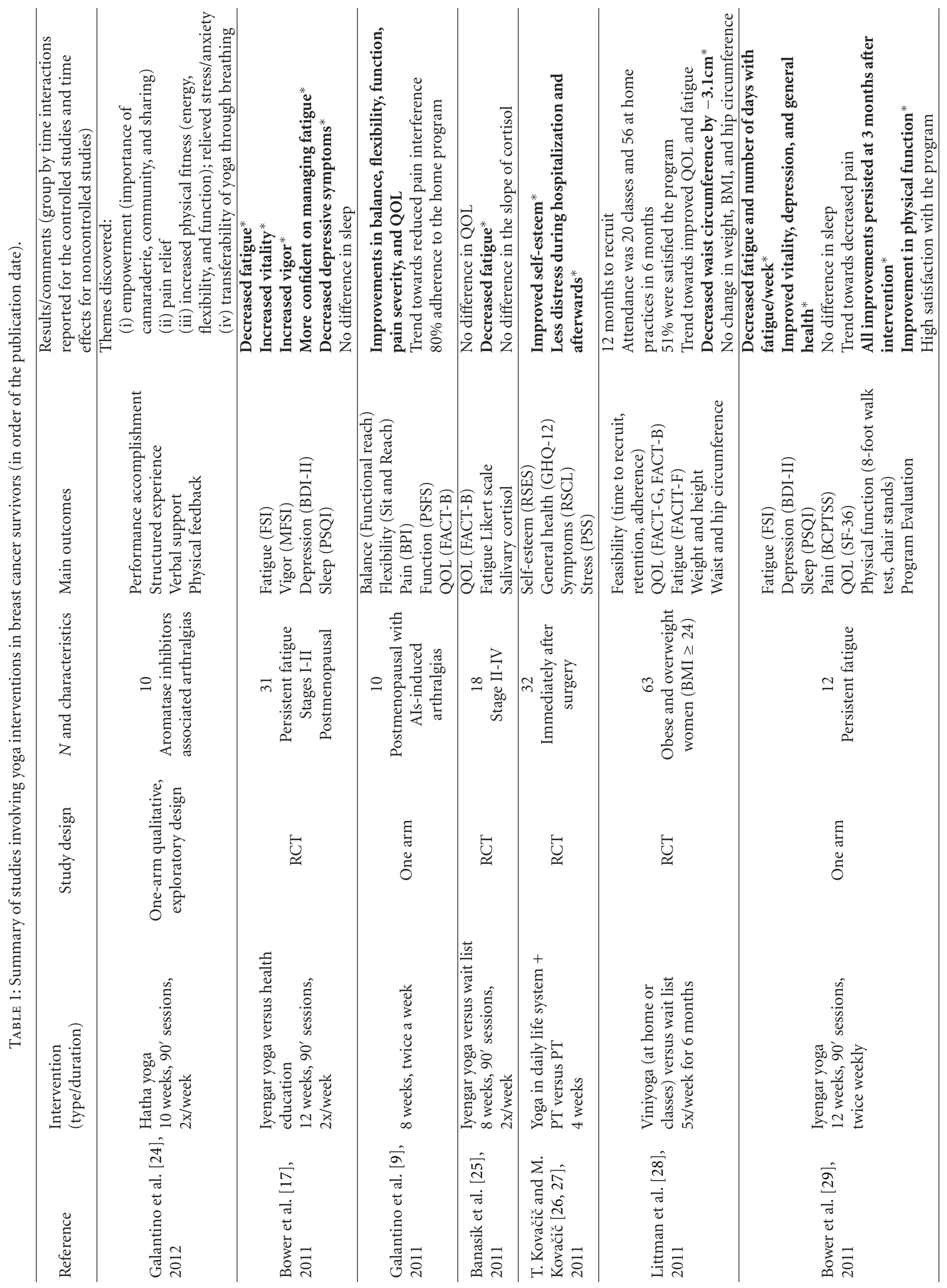




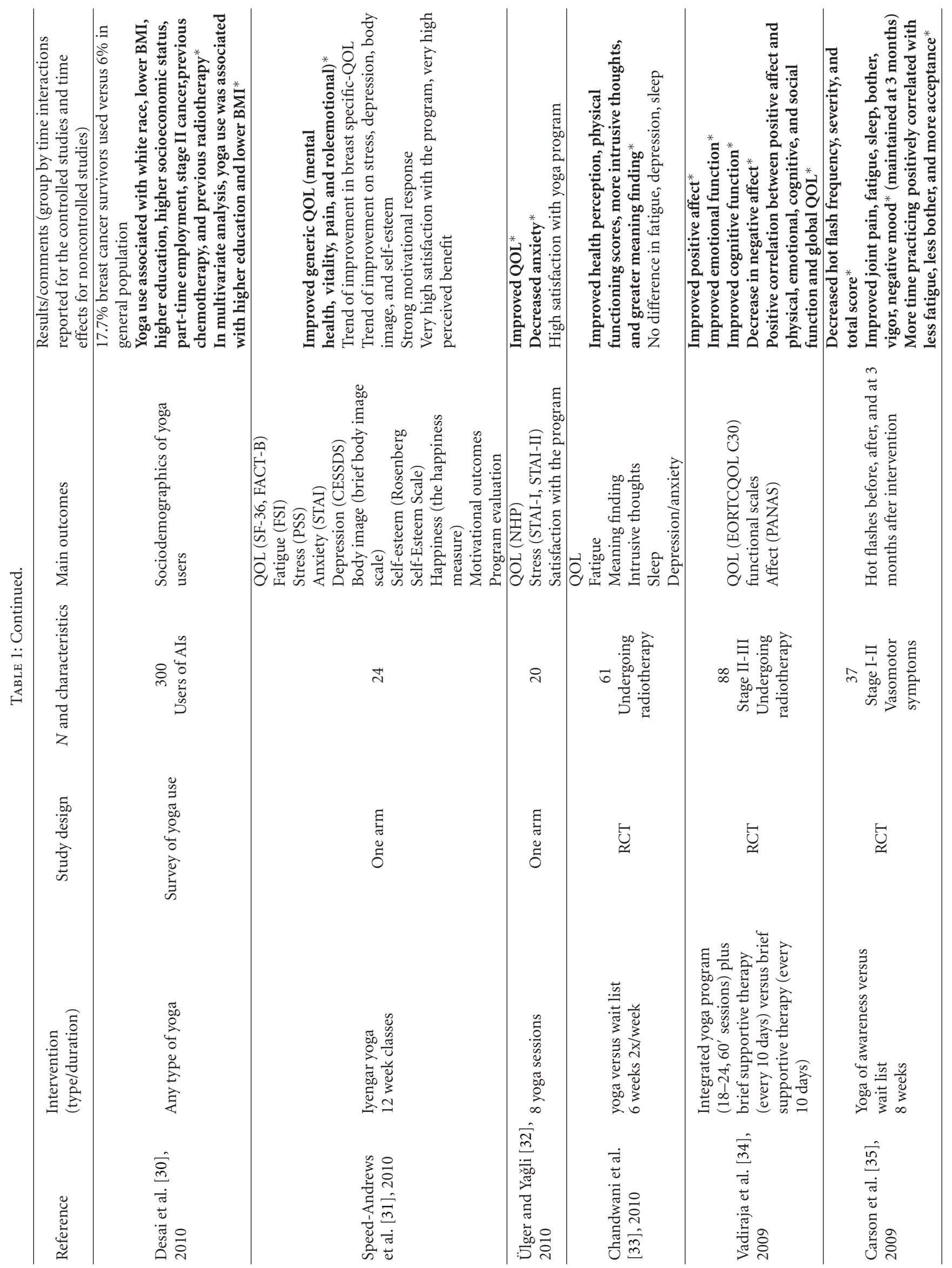




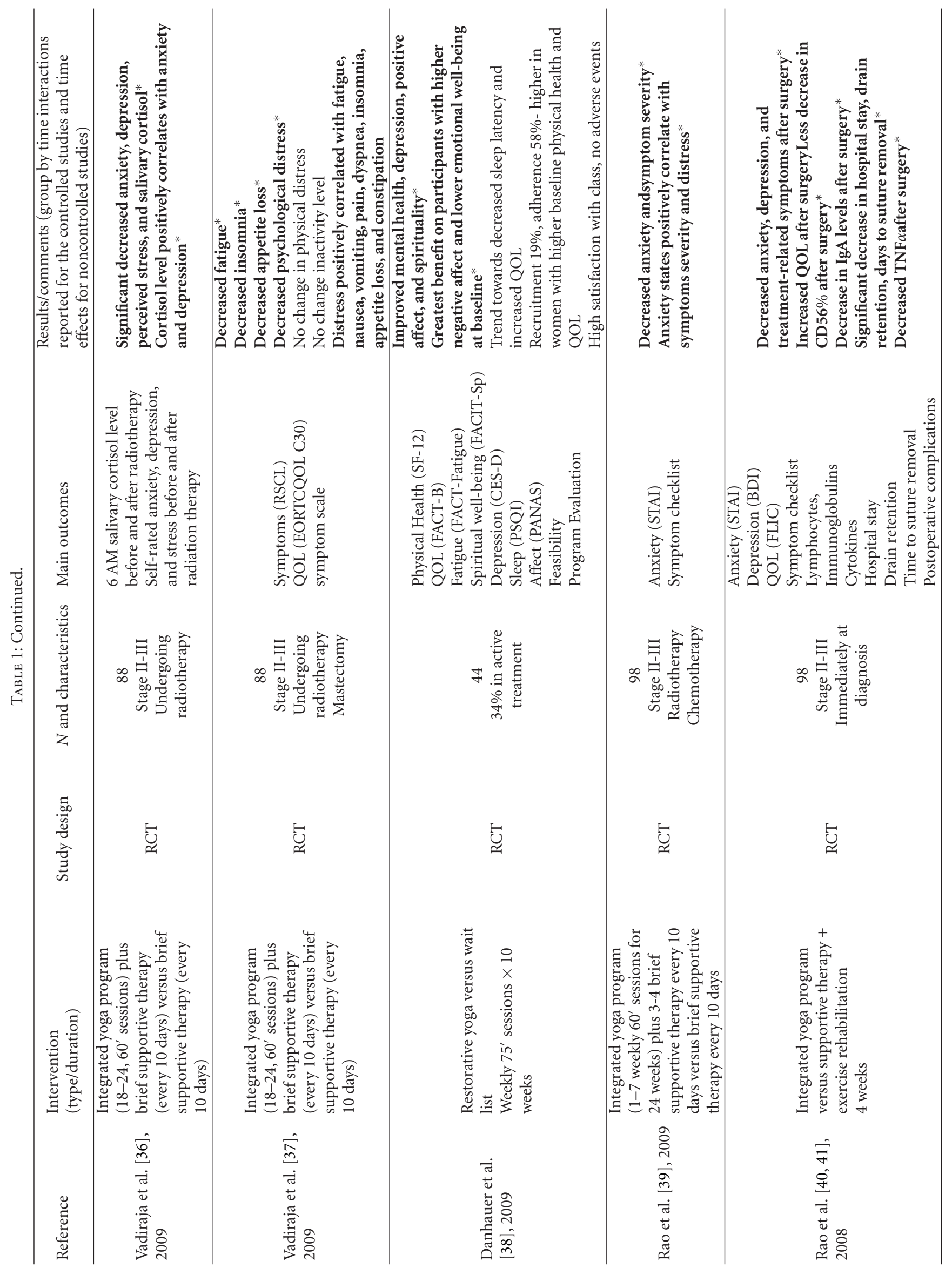




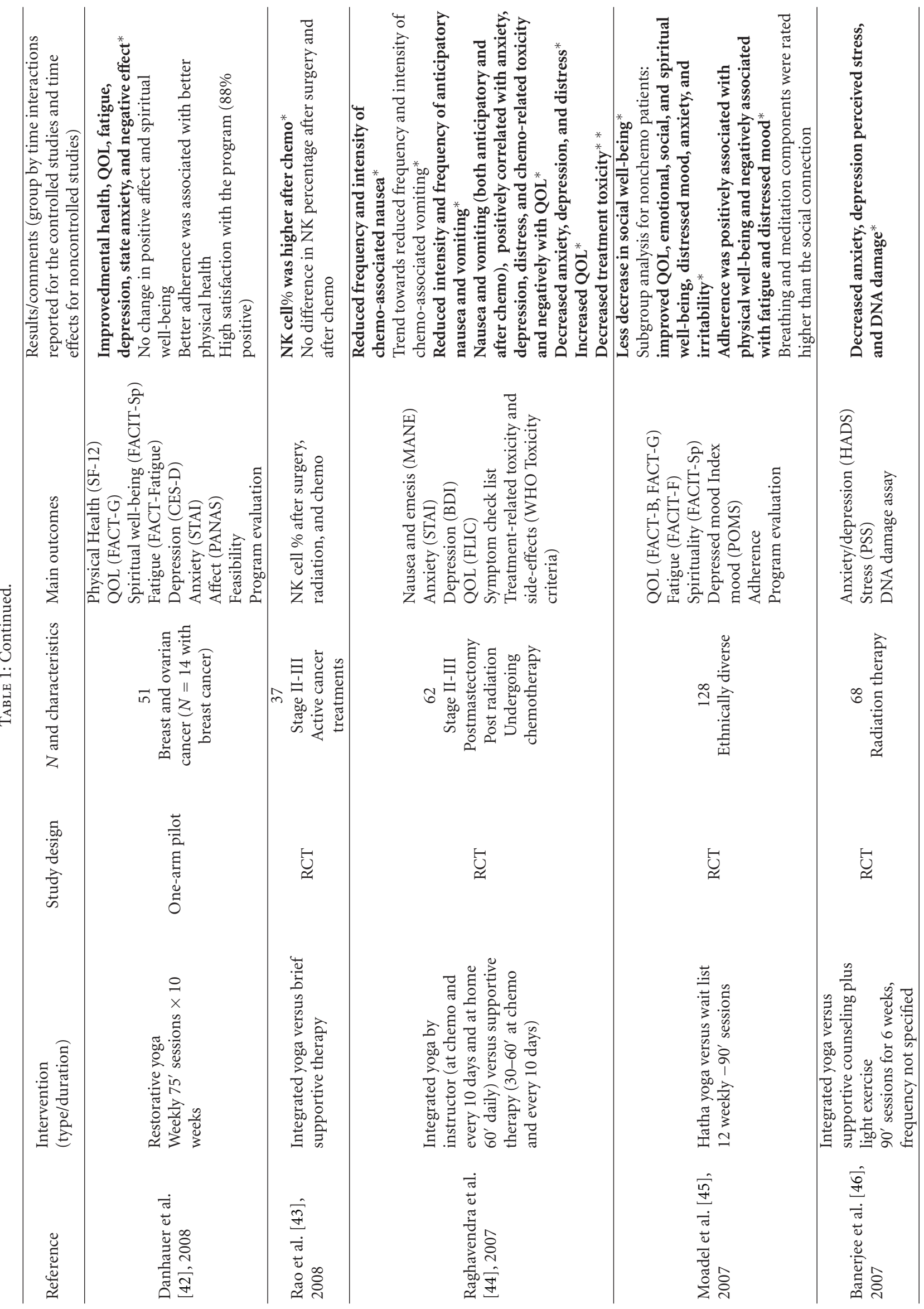




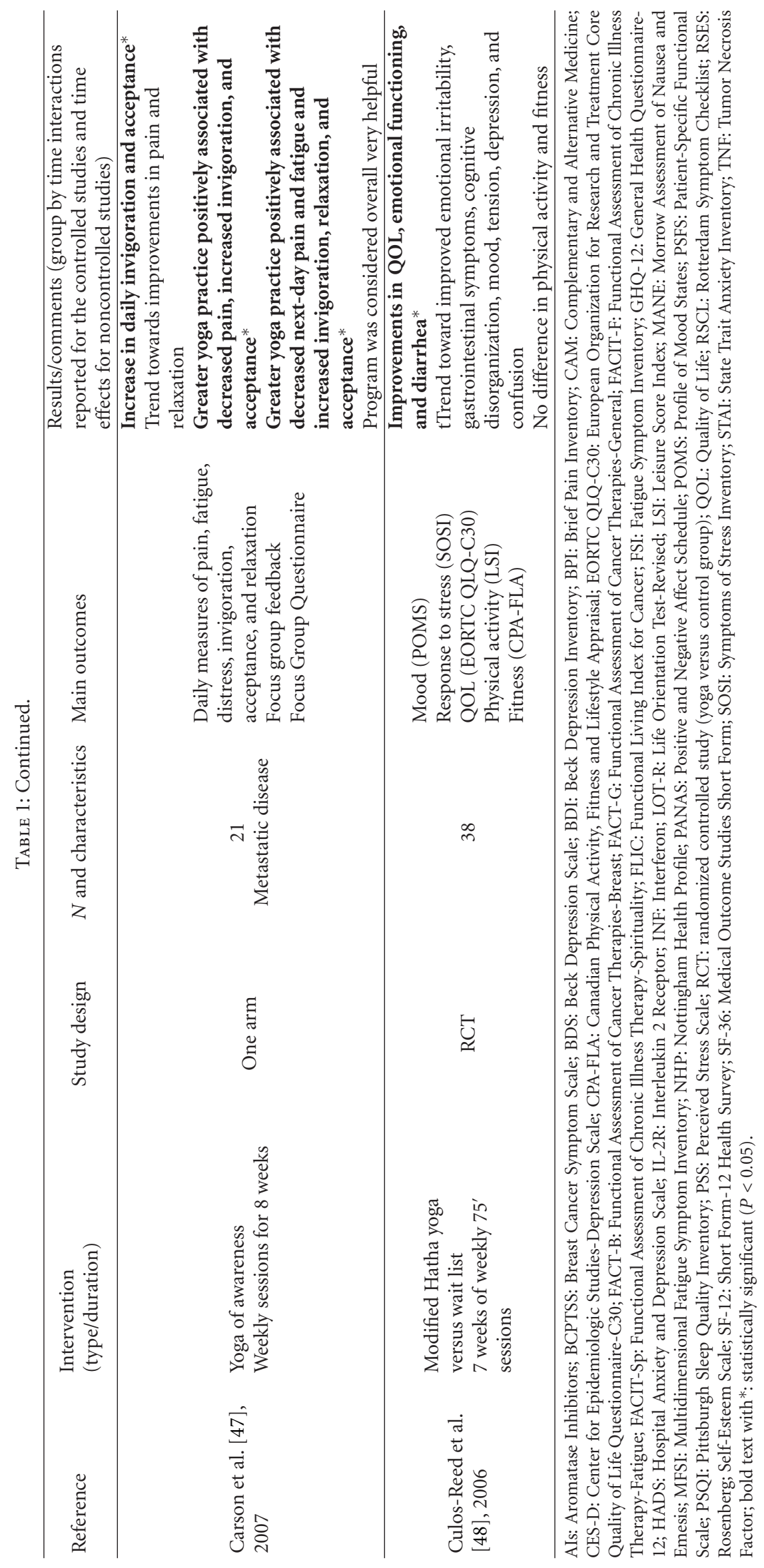


TABLE 2: Studies involving tai chi chuan in breast cancer survivors.

\begin{tabular}{|c|c|c|c|c|c|}
\hline Reference & $\begin{array}{l}\text { Intervention } \\
\text { (type/duration) }\end{array}$ & $\begin{array}{l}\text { Study } \\
\text { design }\end{array}$ & $N$ & Main outcomes & $\begin{array}{l}\text { Comments/results (group by time } \\
\text { interactions reported for the } \\
\text { controlled studies and time effects } \\
\text { for non-controlled studies) }\end{array}$ \\
\hline $\begin{array}{l}\text { Reid-Arndt et al. } \\
{[65], 2012}\end{array}$ & $\begin{array}{l}\text { Yang style tai chi chuan } \\
10 \text { weeks, } 60^{\prime} \text { sessions, } \\
2 x / \text { week }\end{array}$ & One arm & $\begin{array}{l}23 \text { ( } 16 \text { with } \\
\text { breast cancer) } \\
\text { At least } 12 \\
\text { months from } \\
\text { chemotherapy }\end{array}$ & $\begin{array}{l}\text { Neuropsychological tests } \\
\text { (memory, executive } \\
\text { function, language, and } \\
\text { attention) } \\
\text { Self-reported cognitive } \\
\text { functioning (MASQ) } \\
\text { Distress (IES-R) } \\
\text { Mood (POMS-SF) } \\
\text { Fatigue (POMS-SF) } \\
\text { Balance }\end{array}$ & $\begin{array}{l}\text { Improvements in immediate and } \\
\text { delayed memory, verbal fluency, } \\
\text { attention, executive functioning, } \\
\text { and self-reported cognitive } \\
\text { functioning* } \\
\text { Improvements in stress* } \\
\text { Trend toward improved vigor } \\
\text { No changes in fatigue } \\
\text { Improved balance* }\end{array}$ \\
\hline $\begin{array}{l}\text { Sprod et al. [66], } \\
2012\end{array}$ & $\begin{array}{l}\text { Yang style tai chi chuan } \\
\text { versus standard } \\
\text { support therapy } \\
12 \text { weeks, } 60^{\prime} \text { sessions, } \\
3 \mathrm{x} / \text { week }\end{array}$ & RCT & 35 & $\begin{array}{l}\text { HRQOL (MOS SF-36) } \\
\text { IL-6, IL-8 } \\
\text { Glucose } \\
\text { Cortisol } \\
\text { Insulin, IGF-1; IGFBP-1; } \\
\text { IGFBP-3 }\end{array}$ & $\begin{array}{l}\text { Improved physical functioning } \\
\text { and general mental health* } \\
\text { Trends towards improved social } \\
\text { functioning and lack of increase in } \\
\text { insulin levels }\end{array}$ \\
\hline $\begin{array}{l}\text { Janelsins et al. } \\
{[67], 2011}\end{array}$ & $\begin{array}{l}\text { Yang style tai chi chuan } \\
\text { versus psychosocial } \\
\text { support therapy } \\
12 \text { weeks, } 60^{\prime} \text { sessions, } \\
3 \mathrm{x} / \text { week }\end{array}$ & RCT & 19 & $\begin{array}{l}\text { Insulin, IGF-I, IGFBP } \\
\text { Body composition (weight, } \\
\text { bmi, fat mass, fat-free } \\
\text { mass) } \\
\text { Cytokine levels (IL-6, IL-2 } \\
\text { and IFN- } \gamma\end{array}$ & $\begin{array}{l}\text { Lack on increase in insulin } \\
\text { levels* } \\
\text { No change in IGF-1,IGFBP or } \\
\text { cytokines } \\
\text { Decreased BMI* }\end{array}$ \\
\hline $\begin{array}{l}\text { Peppone et al. } \\
{[68], 2010}\end{array}$ & $\begin{array}{l}\text { Yang style tai chi chuan } \\
\text { versus psychosocial } \\
\text { support therapy } \\
12 \text { weeks, } 60^{\prime} \text { sessions, } \\
3 \mathrm{x} / \text { week }\end{array}$ & RCT & 16 & $\begin{array}{l}\text { Bone formation (serum } \\
\text { BSAP) } \\
\text { Bone resorption (serum } \\
\text { NTx) } \\
\text { Bone remodeling index } \\
\text { IGF-1, IGFBP1,3 } \\
\text { Cytokines (IL-2, 6, } 8 \text {, } \\
\text { IFN- } \gamma 2 \text { ) }\end{array}$ & $\begin{array}{l}\text { Trend towards an increase in bone } \\
\text { formation and a decrease in bone } \\
\text { resorption } \\
\text { Improvement in bone } \\
\text { remodeling index* }\end{array}$ \\
\hline $\begin{array}{l}\text { Mustian et al. } \\
{[69-71], 2008 \text {, }} \\
2006,2004\end{array}$ & $\begin{array}{l}\text { Yang style tai chi chuan } \\
\text { versus psychosocial } \\
\text { support therapy } \\
12 \text { weeks, } 60^{\prime} \text { sessions, } \\
3 \mathrm{x} / \text { week }\end{array}$ & RCT & 21 & $\begin{array}{l}\text { Functional capacity } \\
\text { (aerobic capacity, muscle } \\
\text { strength, and flexibility) } \\
\text { QOL (FACIT-Fatigue) } \\
\text { Body composition } \\
\text { Self-esteem (RSE) }\end{array}$ & $\begin{array}{l}\text { Trend toward improvement in } \\
\text { aerobic capacity and flexibility } \\
\text { Improved muscle strength and } \\
\text { QOL at } 12 \text { weeks* } \\
\text { No difference in body composition } \\
\text { Improved self-esteem* } \\
\text { Self-esteem positively correlated } \\
\text { with QOL* }\end{array}$ \\
\hline
\end{tabular}

BSAP: Bone-Specific Alkaline Phosphatase; FACIT-Fatigue: Functional Assessment of Chronic Illness Therapy-Fatigue; HRQOL: health-Related Quality of Life; IGFBP: Insulin-like Growth Factor Binding Protein; IL: Interleukin; IGF: Insulin-like Growth Factor; MASQ: Multiple Abilities Self-Report Questionnaire; NTx: N-Telopeptides of Type I Collagen; IES-R: Impact of Event Scale-Revised; POMS-SF: Profile of Mood States-Short Form; RSE: Rosenberg Self-Esteem Scale; bold text with*: statistically significant $(P<0.05)$.

generally not selected for a medical condition or symptom. Barton and Pachman [80] recommended that trials of mindbody interventions should include symptomatic patients in order for an effect size attributable to the intervention to be measurable. This might explain the heterogeneity of effect sizes observed in a systematic review of the effect of yoga on psychological outcomes in cancer survivors (mostly breast cancer) [81]. This review concluded that, although evidence for benefits exists, these should be interpreted with caution given the methodological flaws of the studies.

One notable exception is a study by Bower et al. [17] that selected a homogeneous population of fatigued (scores of $\leq 50$ on the SF-36 vitality scale) stage 0 -II breast cancer survivors. There was significant improvement in the fatigue level in yoga versus control wait-list intervention with a large effect size $(d=1.5)$, superior to other behavioral interventions is managing fatigue in cancer patients [82].

Fatigue is one of the most commonly assessed outcomes in the studies reviewed. Indeed, one-third of patients with cancer report persistent fatigue at five to ten years from diagnosis [83] and no interventions were clearly shown to improve or decrease the duration of this symptom. Yoga seems to be promising in this regard. A recent systematic review [84] addressing the effects of a yoga intervention on 
TABLe 3: Studies involving Pilates method in breast cancer survivors.

\begin{tabular}{|c|c|c|c|c|c|}
\hline Reference & $\begin{array}{l}\text { Intervention } \\
\text { (type/duration) }\end{array}$ & $\begin{array}{l}\text { Study } \\
\text { design }\end{array}$ & $N$ & Main outcomes & $\begin{array}{l}\text { Comments/results (group by time } \\
\text { interactions reported for the controlled } \\
\text { studies and time effects for non-controlled } \\
\text { studies) }\end{array}$ \\
\hline
\end{tabular}

\begin{tabular}{|c|c|c|c|c|c|}
\hline $\begin{array}{l}\text { Stan et al. [73], } \\
2012\end{array}$ & $\begin{array}{l}\text { Mat Pilates } \\
12 \text { weeks, } 45^{\prime} \text { sessions, } \\
3-5 \mathrm{x} / \text { week } \\
\text { Postmastectomy }\end{array}$ & One arm & $\begin{array}{c}15 \\
\text { All had } \\
\text { mastectomy }\end{array}$ & $\begin{array}{l}\text { Shoulder ROM } \\
\text { Spine flexibility } \\
\text { Height } \\
\text { Arm volumes } \\
\text { QOL (FACT-B) } \\
\text { Mood (POMS) } \\
\text { Body image (MBSRQ) }\end{array}$ & $\begin{array}{l}\text { Improved shoulder abduction and internal } \\
\text { rotation* } \\
\text { Improved neck flexion and rotation } \\
\text { towards the unaffected side* } \\
\text { No difference in spine flexibility and height } \\
\text { Increased arm volume of the affected } \\
\text { compared to the unaffected side } \\
\text { (subclinical lymphedema in } 6 \text { patients)* } \\
\text { Improved QOL and certain scales of mood } \\
\text { and body image* }\end{array}$ \\
\hline
\end{tabular}

\begin{tabular}{|c|c|c|c|c|c|}
\hline $\begin{array}{l}\text { Eyigor et al. } \\
\text { [74], } 2010\end{array}$ & $\begin{array}{l}\text { Mat Pilates plus home } \\
\text { exercise (walking, } \\
\text { stretching, and ROM) } \\
\text { versus home exercises } \\
8 \text { weeks, } 60^{\prime} \text { sessions, } \\
\text { 3x/week }\end{array}$ & RCT & $\begin{array}{c}52 \\
\text { All had } \\
\text { mastectomy }\end{array}$ & $\begin{array}{l}\text { Aerobic capacity } \\
\text { (6MWT) } \\
\text { Flexibility (modified sit } \\
\text { and reach test) } \\
\text { Fatigue (BFI) } \\
\text { Depression (BDI) } \\
\text { QOL } \\
\text { (EORTC-QLQ-C30 and } \\
\text { B23) }\end{array}$ & $\begin{array}{l}\text { Improved aerobic capacity* } \\
\text { No difference in the other outcomes }\end{array}$ \\
\hline
\end{tabular}

6MWT: 6-Minute Walk Test; BFI: Brief fatigue Inventory; BDI: Beck Depression Index; BPI: Brief Pain Inventory; EORTC-QLQ-C30: European Organization for Research and Treatment Cancer-Quality of Life; FACT-B: Functional Assessment of Cancer Therapies-Breast; MBSRQ: Multidimensional Body-SelfRelations Questionnaire; POMS: Profile of Mood States-Short Form; UE: Upper Extremity; bold text with*: statistically significant $(P<0.05)$.

fatigue in breast cancer survivors showed improvement in fatigue scores $(\mathrm{SMD}=0.33$, CI $0.01-0.65, P=0.04)$. In fatigued patients, a low-moderate intensity physical exercise such as yoga might be more appealing and feasible than the regular aerobic exercises. Indeed, in the study by Bower et al. [17] the adherence to the intervention was excellent (80\%), much higher compared to aerobic exercise intervention studies [2]. Furthermore, the program evaluation was excellent in all the studies assessing this outcome, suggesting that yoga is a popular intervention in breast cancer patients.

The lack of an active control group further impacts the methodology of these studies. Only 3 out of 18 RCTs had an active control group of physical activity intervention, whereas 15 were controlled with brief supportive therapy or wait list. Without a control group undergoing a nonmindfulness exercise intervention, it is very challenging to differentiate whether the benefits observed are specific to the yoga intervention or could be attributed to any exercise method or simply to the attention bias (for the studies with a waitlist design). Indeed, a recent systematic review comparing mindfulness-based exercise versus nonmindfulness exercise methods in people with depression has shown benefits from both categories of exercise in reducing the depression level and depression symptoms. A comparison between the two methods was not feasible, given the limitation of designs [18]. This suggests that specifically designed studies that are rigorously conducted need to be performed comparing a mindfulness based versus standard exercise intervention to be able to discern the true and significant benefits of the mindfulness component of an intervention such as yoga.
Another limitation of studies of yoga in breast cancer survivors is their almost exclusive appeal to the high-income, white population. The only study to include an ethnically and economically diverse population [45] reported on the effect of yoga versus usual care wait list in a multiethnic sample of 128 breast cancer survivors. There was no difference in QOL except for less decrease in social well-being in the yoga group. However, in a secondary analysis of the participants not receiving chemotherapy, significant improvements were seen in the overall QOL, emotional well-being, social and spiritual well-being, and less distressed mood in the yoga group compared to the control, wait-list group.

Overall, yoga intervention seems to be beneficial in this population, especially in fatigued patients. However, the results of these studies should be interpreted with caution, given the small sizes and the heterogeneity of the population, outcomes and yoga intervention (duration, frequency, and type of yoga program), and methodological limitations of the studies. Similar conclusions were drawn by a systematic review of the effects of yoga on psychological outcomes in cancer survivors [81] and by a review of integrative therapies in cancer survivors [80].

More rigorous studies of yoga have recently been conducted capturing the attention of the scientific community. A recent clinical trial by Mustian et al. focused on yoga versus usual care in 410 cancer survivors (75\% with breast cancer) with sleep disturbances. This study showed significant improvement in sleep (22\% versus $12 \%)$ and fatigue ( $42 \%$ versus $12 \%$ ) and a significant decrease in the use of sleep medications in the yoga group compared with the 
TABLE 4: Studies involving qigong in breast cancer survivors.

\begin{tabular}{|c|c|c|c|c|c|}
\hline Reference & $\begin{array}{l}\text { Intervention } \\
\text { (type/duration) }\end{array}$ & $\begin{array}{l}\text { Study } \\
\text { design }\end{array}$ & $N$ & Main outcomes & $\begin{array}{l}\text { Comments/results (group by time } \\
\text { interactions reported for the } \\
\text { controlled studies and time effects for } \\
\text { non-controlled studies) }\end{array}$ \\
\hline $\begin{array}{l}\text { Cohen et al. } \\
{[77], 2010}\end{array}$ & $\begin{array}{l}\text { External qigong } \\
\text { (applied by qigong } \\
\text { master) daily }\left(2-5^{\prime}\right) \text { for } \\
5 \text { consecutive days }\end{array}$ & One arm & $\begin{array}{c}9 \\
\text { Untreated } \\
\text { cancer } \\
\text { Tumor size } \leq \\
3 \mathrm{~cm}\end{array}$ & $\begin{array}{l}\text { Tumor size by breast } \\
\text { imaging } \\
\text { QOL (FACT-B) } \\
\text { Distress (BSI) } \\
\text { Cancer-related } \\
\text { symptoms (MIDAS) }\end{array}$ & $\begin{array}{l}\text { No difference in tumor size } \\
\text { No difference in QOL, distress, and } \\
\text { symptoms }\end{array}$ \\
\hline $\begin{array}{l}\text { Oh et al. [7], } \\
2010\end{array}$ & $\begin{array}{l}\text { Medical qigong versus } \\
\text { usual care } \\
10 \text { weeks, } 90^{\prime} \text { sessions } \\
2 \mathrm{x} / \text { week } \\
\text { Home practice } 30^{\prime} \text { daily }\end{array}$ & RCT & $\begin{array}{l}162 \\
\text { Only } 34 \% \text { were } \\
\text { breast cancer } \\
\text { survivors }\end{array}$ & $\begin{array}{l}\text { QOL (FACT-G) } \\
\text { Fatigue } \\
\text { (FACT-Fatigue) } \\
\text { Mood (POMS) } \\
\text { Inflammation (CRP) }\end{array}$ & $\begin{array}{l}\text { Improvements in all domains of } \\
\text { QOL* } \\
\text { Improvement in fatigue* } \\
\text { Improvement in overall mood and all } \\
\text { subscales of mood, except for } \\
\text { anger-hostility and confusion } \\
\text { subscaleImprovement in CRP level* }\end{array}$ \\
\hline $\begin{array}{l}\text { Yeh et al. [78], } \\
2006\end{array}$ & $\begin{array}{l}\text { Chan-Chuang qigong } \\
\text { versus no intervention } \\
21 \text { days }\end{array}$ & CCT & $\begin{array}{c}67 \\
\text { Undergoing } \\
\text { chemotherapy }\end{array}$ & $\begin{array}{l}\mathrm{CBC} \\
\text { (on days } 0,8,15 \text {, and } \\
22 \text { days of } \\
\text { chemotherapy) }\end{array}$ & $\begin{array}{l}\text { No change in WBC, platelets, and } \\
\text { hemoglobin } \\
\text { Better rebound of WBC after } 21 \\
\text { days* }\end{array}$ \\
\hline $\begin{array}{l}\text { Lee et al. [79], } \\
2006\end{array}$ & $\begin{array}{l}\text { Chan-Chuang qigong } \\
\text { versus no intervention } \\
21 \text { days }\end{array}$ & CCT & $\begin{array}{c}67 \\
\text { Undergoing } \\
\text { chemotherapy }\end{array}$ & $\begin{array}{l}\text { Symptom distress } \\
\text { (SDS) } \\
\text { Psychological distress } \\
\text { (SCL-90-R) } \\
\text { (on days } 0,8,15 \text {, and } \\
22 \text { days of } \\
\text { chemotherapy) }\end{array}$ & $\begin{array}{l}\text { Improved overall symptom score at } \\
\text { day } 22^{*} \\
\text { Less numbness and heartburn on day } \\
8 \text {, less pain and numbness on day } 15 \text {, } \\
\text { less pain, numbness, heartburn, and } \\
\text { dizziness on day } 22^{*} \\
\text { No difference in overall psychological } \\
\text { score } \\
\text { Less hopelessness about the future on } \\
\text { day } 8 \text {, less unwillingness to live on } \\
\text { day } 22^{*}\end{array}$ \\
\hline
\end{tabular}

BSI: Brief Symptom Inventory; CRP: C-Reactive Protein; CBC: Complete Blood Count; FACT-B: Functional Assessment of Cancer Therapies-Breast; FACTF: Functional Assessment of Cancer Therapies-Fatigue; POMSs: Profile of Mood States; MDASI: MD Anderson Symptom Inventory; SCL-90-R: Symptom Checklist-Revised; SDS: Symptom Distress Scale; bold text with*: statistically significant $(P<0.05)$.

usual care group [85]. In an abstract presented at the annual meeting of the American Society of Clinical Oncology in 2011, Cohen et al. reported on a study of yoga versus stretching versus control wait-list group on 163 breast cancer survivors undergoing radiotherapy. Yoga and stretching were superior to the control group in improving fatigue and physical functioning. Yoga was superior to the other groups in improving QOL, benefit finding, cortisol slope, and heart rate variability [86]. From these studies and the increasing interest in yoga for cancer survivors and medical institutions, it appears that yoga is establishing itself into the mainstream management and treatment of cancer survivors.

Tai Chi Chuan. The studies of TCC in breast cancer are few, generally small $(N=16-21)$, poorly controlled, and have heterogeneous outcomes. Benefits were shown in improvements in QOL, fat mass, bone formation, aerobic capacity, shoulder ROM, and self-esteem. However, a recent systematic review of this intervention failed to show any benefits attributable to TCC in the four RCTs included in the review [87]. The three, small nonrandomized, controlled clinical trials included in this review did show favorable effects in psychological and physical outcomes, although the risk of bias was high.

Future studies of TCC that include a symptomatic group of breast cancer survivors and compare TCC to other forms of low-impact aerobic exercise may be useful to help understand if the effects seen from TCC are unique to this form of exercise. With the increasing recognition of the importance of metabolic abnormalities such as hyperinsulinemia [88] in the prognosis of breast cancer, and of the prevalence of longterm sequelae such as metabolic bone disease [89] in this population, rigorous studies of tai chi chuan, a low-impact exercise intervention shown to improve these outcomes in noncancer patients, should be conducted.

Pilates. The study of the Pilates method in breast cancer survivors is underrepresented (only three studies exist addressing this method, one being a case series $[73,74,90]$ ), in contrast to the intense advertising of this method in the rehabilitation of breast cancer survivors. The evidence from these studies showed improvements in aerobic capacity, 
QOL, mood, body image after mastectomy, and improved shoulder ROM, as well as potential concerns of lymphedema. These findings are also limited by the small size and the limited research performed in this area. No studies of Pilates in survivors of types of cancer other than breast were conducted. Strong evidence to support Pilates as an effective rehabilitation method after breast cancer treatment is lacking at this time.

Qigong. The four studies of qigong in breast cancer survivors all have different outcomes. A small $(N=9)$ non-controlled study reported on the effects of externally applied qigong, by a qigong master, to the cancerous mass, failing to reveal a change in size or a change in psychological outcomes. The other three studies report on the effects of qigong practiced by the participants. The largest of these studies $(N=162)$ and with the strongest methodology did show significant improvements in QOL, fatigue, mood, and CRP levels [7], but only 34\% of the participants in this study had breast cancer. A recent systematic review of qigong in cancer survivors has shown a significant improvement in the immune function, but no conclusion could be drawn towards psychological outcomes, due to the heterogeneity of the outcomes and the methodological flaws [91]. At this time, not enough evidence exists to recommend the use of qigong for breast cancer patients.

\section{Conclusion}

Our review has found that studies of mindful exercise interventions in breast cancer survivors are generally small, poorly controlled, and the outcomes are heterogeneous. With the exception of evidence that yoga improves fatigue in breast cancer survivors, no other strong conclusions can be derived, given the methodological limitations of the studies.

The significant interest by both patients and health care providers to integrate CAM therapies into the management of breast cancer survivors should hopefully lead to more effort and attention given to incorporating evidence-based CAM knowledge into clinical care. In this age of evidencebased medicine, CAM researchers will be expected to conduct RCTs that are adequately powered, well designed, and controlled, and with scrupulous attention paid to eliminating sources of bias. A multidisciplinary approach, in combination with personalized programs, has now become the state-of-the-art management of breast cancer. It is prudent that CAM researchers conducting clinical trials prioritize the need to assess safety, efficacy, and long-term benefits, while attempting to define the position of CAM in this complex therapeutic approach. With supporting evidence, health care providers are in a better position to educate survivors of breast cancer, help them make evidencebased decisions, and recommend CAM therapies that are demonstrated to improve QOL of their patients.

\section{Acknowledgments}

The authors gratefully acknowledge the invaluable guidance in the writing of this paper from Brent Bauer, MD and
Mrs. Gladys Hebl, from Mayo Clinic Grant and Publication Support Services, who helped with the preparation and submission of the manuscript.

\section{References}

[1] National Cancer Institute, "Surveillance Epidemiology and End Results, Cancer Statistics," http://seer.cancer.gov/statistics/.

[2] K. S. Courneya, R. J. Segal, J. R. Mackey et al., "Effects of aerobic and resistance exercise in breast cancer patients receiving adjuvant chemotherapy: a multicenter randomized controlled trial," Journal of Clinical Oncology, vol. 25, no. 28, pp. 4396-4404, 2007.

[3] K. H. Schmitz, R. L. Ahmed, A. Troxel et al., "Weight lifting in women with breast-cancer-related lymphedema," New England Journal of Medicine, vol. 361, no. 7, pp. 664-673, 2009.

[4] A. H. Eliassen, S. E. Hankinson, B. Rosner, M. D. Holmes, and W. C. Willett, "Physical activity and risk of breast cancer among postmenopausal women," Archives of Internal Medicine, vol. 170, no. 19, pp. 1758-1764, 2010.

[5] M. D. Holmes, W. Y. Chen, D. Feskanich, C. H. Kroenke, and G. A. Colditz, "Physical activity and survival after breast cancer diagnosis," Journal of the American Medical Association, vol. 293, no. 20, pp. 2479-2486, 2005.

[6] C. Buettner, C. H. Kroenke, R. S. Phillips, R. B. Davis, D. M. Eisenberg, and M. D. Holmes, "Correlates of use of different types of complementary and alternative medicine by breast cancer survivors in the nurses' health study," Breast Cancer Research and Treatment, vol. 100, no. 2, pp. 219-227, 2006.

[7] B. Oh, P. Butow, B. Mullan et al., "Impact of Medical Qigong on quality of life, fatigue, mood and inflammation in cancer patients: a randomized controlled trial," Annals of Oncology, vol. 21, no. 3, pp. 608-614, 2010.

[8] P. Mansky, T. Sannes, D. Wallerstedt et al., "Tai chi chuan: mind-body practice or exercise intervention? Studying the benefit for cancer survivors," Integrative Cancer Therapies, vol. 5, no. 3, pp. 192-201, 2006.

[9] M. L. Galantino, K. Desai, L. Greene, A. Demichele, C. T. Stricker, and J. J. Mao, "Impact of yoga on functional outcomes in breast cancer survivors with aromatase inhibitorassociated arthralgias," Integrative Cancer Therapies. In press.

[10] L. E. Carlson, M. Speca, K. D. Patel, and E. Goodey, "Mindfulness-based stress reduction in relation to quality of life, mood, symptoms of stress and levels of cortisol, dehydroepiandrosterone sulfate (DHEAS) and melatonin in breast and prostate cancer outpatients," Psychoneuroendocrinology, vol. 29, no. 4, pp. 448-474, 2004.

[11] M. A. Richardson, T. Sanders, J. L. Palmer, A. Greisinger, and S. E. Singletary, "Complementary/alternative medicine use in a comprehensive cancer center and the implications for oncology," Journal of Clinical Oncology, vol. 18, no. 13, pp. 2505$2514,2000$.

[12] K. T. Morris, N. Johnson, L. Homer, and D. Walts, "A comparison of complementary therapy use between breast cancer patients and patients with other primary tumor sites," American Journal of Surgery, vol. 179, no. 5, pp. 407-411, 2000.

[13] G. Wyatt, A. Sikorskii, C. E. Wills, and H. Su, "Complementary and alternative medicine use, spending, and quality of life in early stage breast cancer," Nursing Research, vol. 59, no. 1, pp. 58-66, 2010. 
[14] National Center for Complementary and Alternative Medicine, "What Is Complementary and Alternative Medicine?" http://nccam.nih.gov/health/whatiscam\#types .

[15] Sporting Goods Manufacturers Association, "Sports Participation in America 2010," http://www.sgma.com/reports/ 270_Sports-Participation-in-America-2010.

[16] C. Wang, R. Bannuru, J. Ramel, B. Kupelnick, T. Scott, and C. H. Schmid, "Tai Chi on psychological well-being: systematic review and meta-analysis," BMC Complementary and Alternative Medicine, vol. 10, article 23, 2010.

[17] J. E. Bower, D. Garet, B. Sternlieb et al., "Yoga for persistent fatigue in breast cancer survivors: a randomized controlled trial," Cancer, vol. 118, no. 15, pp. 3766-3775, 2012.

[18] H. W. H. Tsang, E. P. Chan, and W. M. Cheung, "Effects of mindful and non-mindful exercises on people with depression: a systematic review," British Journal of Clinical Psychology, vol. 47, no. 3, pp. 303-322, 2008.

[19] S. B. S. Khalsa, "Yoga as a therapeutic intervention: a bibliometric analysis of published research studies," Indian Journal of Physiology and Pharmacology, vol. 48, no. 3, pp. 269-285, 2004.

[20] G. Kirkwood, H. Rampes, V. Tuffrey, J. Richardson, and K. Pilkington, "Yoga for anxiety: a systematic review of the research evidence," British Journal of Sports Medicine, vol. 39, no. 12, pp. 884-891, 2005.

[21] K. Pilkington, G. Kirkwood, H. Rampes, and J. Richardson, "Yoga for depression: the research evidence," Journal of Affective Disorders, vol. 89, no. 1-3, pp. 13-24, 2005.

[22] W. J. Broad, The Science of Yoga: The Myths and the Rewards, Simon \& Schuster, New York, NY, USA, 2012.

[23] National Center for Complementary and Alternative Medicine, "Yoga for Health: An Introduction," http://nccam.nih .gov/health/yoga/introduction.htm.

[24] M. L. Galantino, L. Greene, B. Archetto et al., "A qualitative exploration of the impact of yoga on breast cancer survivors with aromatase inhibitor-associated arthralgias," Explore, vol. 8, no. 1, pp. 40-47, 2012.

[25] J. Banasik, H. Williams, M. Haberman, S. E. Blank, and R. Bendel, "Effect of Iyengar yoga practice on fatigue and diurnal salivary cortisol concentration in breast cancer survivors," Journal of the American Academy of Nurse Practitioners, vol. 23, no. 3, pp. 135-142, 2011.

[26] T. Kovačič and M. Kovačičc "Impact of relaxation training according to yoga in daily life system on self-esteem after breast cancer surgery," Journal of Alternative and Complementary Medicine, vol. 17, no. 12, pp. 1157-1164, 2011.

[27] T. Kovačič and M. Kovačič, "Impact of relaxation training according to Yoga in Daily Life $\mathbb{R}$ system on perceived stress after breast cancer surgery," Integrative Cancer Therapies, vol. 10, no. 1, pp. 16-26, 2011.

[28] A. J. Littman, L. C. Bertram, R. Ceballos et al., "Randomized controlled pilot trial of yoga in overweight and obese breast cancer survivors: effects on quality of life and anthropometric measures," Supportive Care in Cancer, vol. 20, pp. 267-277, 2011.

[29] J. E. Bower, D. Garet, and B. Sternlieb, "Yoga for persistent fatigue in breast cancer survivors: results of a pilot study," Evidence-Based Complementary and Alternative Medicine, vol. 2011, Article ID 623168, 8 pages, 2011.

[30] K. Desai, M. A. Bowman, M. L. Galantino et al., "Predictors of yoga use among patients with breast cancer," Explore, vol. 6, no. 6, pp. 359-363, 2010.

[31] A. E. Speed-Andrews, C. Stevinson, L. J. Belanger, J. J. Mirus, and K. S. Courneya, "Pilot evaluation of an Iyengar yoga program for breast cancer survivors," Cancer Nursing, vol. 33, no. 5, pp. 369-381, 2010.

[32] O. Ülger and N. V. Yağli, "Effects of yoga on the quality of life in cancer patients," Complementary Therapies in Clinical Practice, vol. 16, no. 2, pp. 60-63, 2010.

[33] K. D. Chandwani, B. Thornton, G. H. Perkins et al., "Yoga improves quality of life and benefit finding in women undergoing radiotherapy for breast cancer," Journal of the Society for Integrative Oncology, vol. 8, no. 2, pp. 43-55, 2010.

[34] H. S. Vadiraja, M. R. Rao, R. Nagarathna et al., "Effects of yoga program on quality of life and affect in early breast cancer patients undergoing adjuvant radiotherapy: a randomized controlled trial," Complementary Therapies in Medicine, vol. 17, no. 5-6, pp. 274-280, 2009.

[35] J. W. Carson, K. M. Carson, L. S. Porter, F. J. Keefe, and V. L. Seewaldt, "Yoga of Awareness program for menopausal symptoms in breast cancer survivors: results from a randomized trial," Supportive Care in Cancer, vol. 17, no. 10, pp. 13011309, 2009.

[36] H. S. Vadiraja, R. M. Raghavendra, R. Nagarathna et al., "Effects of a Yoga program on cortisol rhythm and mood states in early breast cancer patients undergoing adjuvant radiotherapy: a randomized controlled trial," Integrative Cancer Therapies, vol. 8, no. 1, pp. 37-46, 2009.

[37] S. H. Vadiraja, M. R. Rao, and R. H. Nagendra, "Effects of yoga on symptom management in breast cancer patients: a randomized controlled trial," International Journal of Yoga, vol. 2, pp. 73-79, 2009.

[38] S. C. Danhauer, S. L. Mihalko, G. B. Russell et al., "Restorative yoga for women with breast cancer: finding from a randomized pilot study," Psycho-Oncology, vol. 18, no. 4, pp. 360-368, 2009.

[39] M. R. Rao, N. Raghuram, H. R. Nagendra et al., "Anxiolytic effects of a yoga program in early breast cancer patients undergoing conventional treatment: a randomized controlled trial," Complementary Therapies in Medicine, vol. 17, no. 1, pp. $1-8,2009$.

[40] R. M. Rao, H. R. Nagendra, N. Raghuram et al., "Influence of yoga on postoperative outcomes and wound healing in early operable breast cancer patients undergoing surgery," International Journal of Yoga, vol. 1, pp. 33-41, 2008.

[41] R. M. Rao, H. R. Nagendra, N. Raghuram et al., "Influence of yoga on mood states, distress, quality of life and immune outcomes in early stage breast cancer patients undergoing surgery," International Journal of Yoga, vol. 1, pp. 11-20, 2008.

[42] S. C. Danhauer, J. A. Tooze, D. F. Farmer et al., "Restorative yoga for women with ovarian or breast cancer: findings from a pilot study," Journal of the Society for Integrative Oncology, vol. 6, no. 2, pp. 47-58, 2008.

[43] R. M. Rao, S. Telles, H. R. Nagendra et al., "Effects of yoga on natural killer cell counts in early breast cancer patients undergoing conventional treatment. Comment to: recreational music-making modulates natural killer cell activity, cytokines, and mood states in corporate employees Masatada Wachi, Masahiro Koyama, Masanori Utsuyama, Barry B. Bittman, Masanobu Kitagawa, Katsuiku Hirokawa Medical Science Monitor, vol. 13, no. 2, PP. CR57-CR70, 2007," Medical Science Monitor, vol. 14, pp. LE3-LE4, 2008.

[44] R. M. Raghavendra, R. Nagarathna, H. R. Nagendra et al., "Effects of an integrated yoga programme on chemotherapyinduced nausea and emesis in breast cancer patients," European Journal of Cancer Care, vol. 16, no. 6, pp. 462-474, 2007.

[45] A. B. Moadel, C. Shah, J. Wylie-Rosett et al., "Randomized controlled trial of yoga among a multiethnic sample of breast 
cancer patients: effects on quality of life," Journal of Clinical Oncology, vol. 25, no. 28, pp. 4387-4395, 2007.

[46] B. Banerjee, H. S. Vadiraj, A. Ram et al., "Effects of an integrated yoga program in modulating psychological stress and radiation-induced genotoxic stress in breast cancer patients undergoing radiotherapy," Integrative Cancer Therapies, vol. 6, no. 3, pp. 242-250, 2007.

[47] J. W. Carson, K. M. Carson, L. S. Porter, F. J. Keefe, H. Shaw, and J. M. Miller, "Yoga for women with metastatic breast cancer: results from a pilot study," Journal of Pain and Symptom Management, vol. 33, no. 3, pp. 331-341, 2007.

[48] S. N. Culos-Reed, L. E. Carlson, L. M. Daroux, and S. HatelyAldous, "A pilot study of yoga for breast cancer survivors: physical and psychological benefits," Psycho-Oncology, vol. 15, no. 10, pp. 891-897, 2006.

[49] G. Y. Yeh, E. P. McCarthy, P. M. Wayne et al., “Tai chi exercise in patients with chronic heart failure: a randomized clinical trial," Archives of Internal Medicine, vol. 171, no. 8, pp. 750757, 2011.

[50] S. L. Wolf, R. W. Sattin, M. Kutner, M. O'Grady, A. I. Greenspan, and R. J. Gregor, "Intense Tai Chi exercise training and fall occurrences in older, transitionally frail adults: a randomized, controlled trial," Journal of the American Geriatrics Society, vol. 51, no. 12, pp. 1693-1701, 2003.

[51] M. Tousignant, H. Corriveau, P.-M. Roy et al., "The effect of supervised Tai Chi intervention compared to a physiotherapy program on fall-related clinical outcomes: a randomized clinical trial," Disability and Rehabilitation, vol. 34, no. 3, pp. 196-201, 2012.

[52] G. Caminiti, M. Volterrani, G. Marazzi et al., "Tai Chi enhances the effects of endurance training in the rehabilitation of elderly patients with chronic heart failure," Rehabilitation Research and Practice, vol. 2011, Article ID 761958, 6 pages, 2011.

[53] C. Wang, R. Roubenoff, J. Lau et al., "Effect of Tai Chi in adults with rheumatoid arthritis," Rheumatology, vol. 44, no. 5, pp. 685-687, 2005.

[54] K. Chan, L. Qin, M. Lau et al., "A randomized, prospective study of the effects of Tai Chi Chun exercise on bone mineral density in postmenopausal women," Archives of Physical Medicine and Rehabilitation, vol. 85, no. 5, pp. 717-722, 2004.

[55] C. Wang, C. H. Schmid, R. Rones et al., "A randomized trial of tai chi for fibromyalgia," New England Journal of Medicine, vol. 363, no. 8, pp. 743-754, 2010.

[56] F. Li, P. Harmer, K. Fitzgerald et al., "Tai chi and postural stability in patients with Parkinson's disease," New England Journal of Medicine, vol. 366, no. 6, pp. 511-519, 2012.

[57] B. Levine, B. Kaplanek, D. Scafura, and W. L. Jaffe, "Rehabilitation after total hip and knee arthroplasty: a new regimen using pilates training," Bulletin of the NYU Hospital for Joint Diseases, vol. 65, no. 2, pp. 120-125, 2007.

[58] D. Shand, "Pilates to pit," Lancet, vol. 363, no. 9418, p. 1340, 2004.

[59] J. A. Kloubec, "Pilates for improvement ofmuscle endurance, flexibility, balance, and posture," Journal of Strength and Conditioning Research, vol. 24, no. 3, pp. 661-667, 2010.

[60] R. Rydeard, A. Leger, and D. Smith, "Pilates-based therapeutic exercise: effect on subjects with nonspecific chronic low back pain and functional disability: a randomized controlled trial," Journal of Orthopaedic and Sports Physical Therapy, vol. 36, no. 7, pp. 472-484, 2006.
[61] B. Levine, B. Kaplanek, and W. L. Jaffe, "Pilates training for use in rehabilitation after total hip and knee arthroplasty a preliminary report," Clinical Orthopaedics and Related Research, vol. 467, no. 6, pp. 1468-1475, 2009.

[62] L. Altan, N. Korkmaz, Ü. Bingol, and B. Gunay, "Effect of pilates training on people with fibromyalgia syndrome: a pilot study," Archives of Physical Medicine and Rehabilitation, vol. 90, no. 12, pp. 1983-1988, 2009.

[63] B. G. D. Siqueira Rodrigues, S. Ali Cader, N. V. O. Bento Torres, E. M. D. Oliveira, and E. H. Martin Dantas, "Pilates method in personal autonomy, static balance and quality of life of elderly females," Journal of Bodywork and Movement Therapies, vol. 14, no. 2, pp. 195-202, 2010.

[64] C. Lange, V. B. Unnithan, E. Larkam, and P. M. Latta, "Maximizing the benefits of Pilates-inspired exercise for learning functional motor skills," Journal of Bodywork and Movement Therapies, vol. 4, no. 2, pp. 99-108, 2000.

[65] S. A. Reid-Arndt, S. Matsuda, and C. R. Cox, "Tai Chi effects on neuropsychological, emotional, and physical functioning following cancer treatment: a pilot study," Complementary Therapies in Clinical Practice, vol. 18, pp. 26-30, 2012.

[66] L. K. Sprod, M. C. Janelsins, O. G. Palesh et al., "Healthrelated quality of life and biomarkers in breast cancer survivors participating in tai chi chuan," Journal of Cancer Survivorship, vol. 6, no. 2, pp. 146-154, 2012.

[67] M. C. Janelsins, P. G. Davis, L. Wideman et al., "Effects of Tai Chi Chuan on insulin and cytokine levels in a randomized controlled pilot study on breast cancer survivors," Clinical Breast Cancer, vol. 11, no. 3, pp. 161-170, 2011.

[68] L. J. Peppone, K. M. Mustian, M. C. Janelsins et al., "Effects of a structured weight-bearing exercise program on bone metabolism among breast cancer survivors: a feasibility trial," Clinical Breast Cancer, vol. 10, no. 3, pp. 224-229, 2010.

[69] K. Mustian, O. Palesh, and S. Flecksteiner, "Tai Chi Chuan for breast cancer survivors," Medicine and Sport Science, vol. 52, pp. 209-217, 2008.

[70] K. M. Mustian, J. A. Katula, and H. Zhao, "A pilot study to assess the influence of Tai Chi Chuan on functional capacity among breast cancer survivors," Journal of Supportive Oncology, vol. 4, no. 3, pp. 139-145, 2006.

[71] K. M. Mustian, J. A. Katula, D. L. Gill, J. A. Roscoe, D. Lang, and K. Murphy, "Tai Chi Chuan, health-related quality of life and self-esteem: a randomized trial with breast cancer survivors," Supportive Care in Cancer, vol. 12, no. 12, pp. 871876, 2004.

[72] B. Oh, P. Butow, B. Mullan et al., "A critical review of the effects of medical Qigong on quality of life, immune function, and survival in cancer patients," Integrative Cancer Therapies, vol. 11, no. 2, pp. 101-110, 2012.

[73] D. L. Stan, S. M. Rausch, K. Sundt et al., "Pilates for breast cancer survivors," Clinical Journal of Oncology Nursing, vol. 16, pp. 131-141, 2012.

[74] S. Eyigor, H. Karapolat, H. Yesil, R. Uslu, and B. Durmaz, "Effects of pilates exercises on functional capacity, flexibility, fatigue, depression and quality of life in female breast cancer patients: a randomized controlled study," European Journal of Physical and Rehabilitation Medicine, vol. 46, no. 4, pp. 481487, 2010.

[75] L. E. Carlson, M. Speca, K. D. Patel, and E. Goodey, "Mindfulness-based stress reduction in relation to quality of life, mood, symptoms of stress, and immune parameters in breast 
and prostate cancer outpatients," Psychosomatic Medicine, vol. 65, no. 4, pp. 571-581, 2003.

[76] O. Paltiel, M. Avitzour, T. Peretz et al., "Determinants of the use of complementary therapies by patients with cancer," Journal of Clinical Oncology, vol. 19, no. 9, pp. 2439-2448, 2001.

[77] L. Cohen, Z. Chen, B. Arun et al., "External qigong therapy for women with breast cancer prior to surgery," Integrative Cancer Therapies, vol. 9, no. 4, pp. 348-353, 2010.

[78] M. L. Yeh, T. I. Lee, H. H. Chen, and T. Y. Chao, "The influences of Chan-Chuang qi-gong therapy on complete blood cell counts in breast cancer patients treated with chemotherapy," Cancer Nursing, vol. 29, no. 2, pp. 149-155, 2006.

[79] T. I. Lee, H. H. Chen, and M. L. Yeh, "Effects of ChanChuang Qigong on improving symptom and psychological distress in chemotherapy patients," American Journal of Chinese Medicine, vol. 34, no. 1, pp. 37-46, 2006.

[80] D. L. Barton and D. R. Pachman, "Clinical trials in integrative therapies," Seminars in Oncology Nursing, vol. 28, no. 1, pp. 10-28, 2012.

[81] K. B. Smith and C. F. Pukall, "An evidence-based review of yoga as a complementary intervention for patients with cancer," Psycho-Oncology, vol. 18, no. 5, pp. 465-475, 2009.

[82] P. B. Jacobsen, K. A. Donovan, S. T. Vadaparampil, and B. J. Small, "Systematic review and meta-analysis of psychological and activity-based interventions for cancer-related fatigue," Health Psychology, vol. 26, no. 6, pp. 660-667, 2007.

[83] J. E. Bower, P. A. Ganz, K. A. Desmond et al., "Fatigue in longterm breast carcinoma survivors: a longitudinal investigation," Cancer, vol. 106, no. 4, pp. 751-758, 2006.

[84] H. Cramer, S. Lange, P. Klose, A. Paul, and G. Dobos, "Can yoga improve fatigue in breast cancer patients? A systematic review," Acta Oncologica, vol. 51, pp. 559-560, 2012.

[85] K. M. Mustian, O. Palesh, L. Sprod et al., "Effect of YOCAS yoga on sleep, fatigue, and quality of life: a URCC CCOP randomized, controlled clinical trial among 410 cancer survivors," Journal of Clinical Oncology, vol. 28, no. 15s, supplement, Abstract 9013, 2010.

[86] L. Cohen, K. Chandwani, N. V. Raghuram et al., "Effect of yoga on QOL, cortisol rhythym, and HRV for women with breast cancer undergoing radiotherapy," Journal of Clinical Oncology, vol. 29, supplement, abstract 9009, 2011.

[87] M. S. Lee, T. Y. Choi, and E. Ernst, "Tai chi for breast cancer patients: a systematic review," Breast Cancer Research and Treatment, vol. 120, no. 2, pp. 309-316, 2010.

[88] V. Formica, M. Tesauro, C. Cardillo, and M. Roselli, "Insulinemia and the risk of breast cancer and its relapse," Diabetes, Obesity and Metabolism. In press.

[89] A. Howell, J. Cuzick, M. Baum et al., "Results of the ATAC (Arimidex, Tamoxifen, Alone or in Combination) trial after completion of 5 years' adjuvant treatment for breast cancer," Lancet, vol. 365, no. 9453, pp. 60-62, 2005.

[90] K. S. Keays, S. R. Harris, J. M. Lucyshyn, and D. L. MacIntyre, "Effects of pilates exercises on shoulder range of motion, pain, mood, and upper-extremity function in women living with breast cancer: a pilot study," Physical Therapy, vol. 88, no. 4, pp. 494-510, 2008.

[91] C. L. Chan, C. W. Wang, R. T. Ho et al., "A systematic review of the effectiveness of qigong exercise in supportive cancer care," Support Care Cancer, vol. 20, pp. 1121-1133, 2012. 


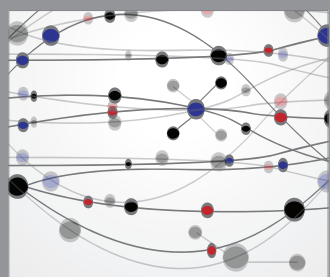

The Scientific World Journal
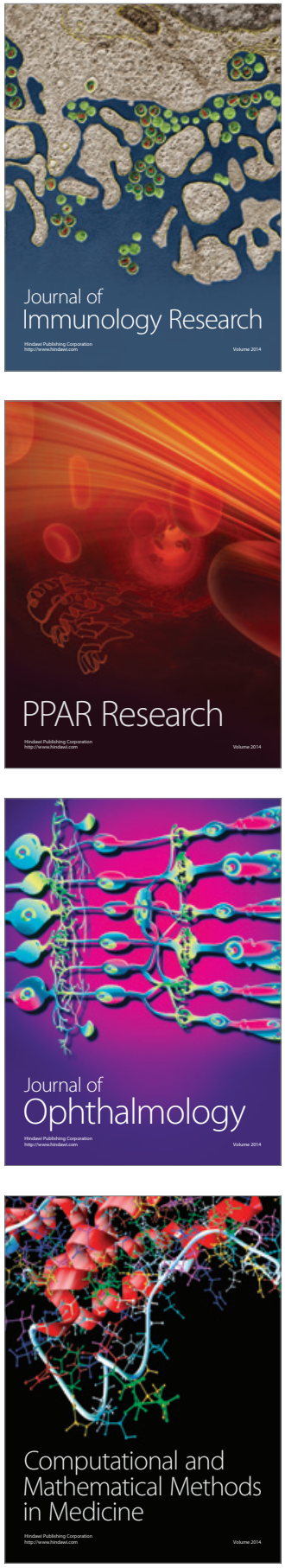

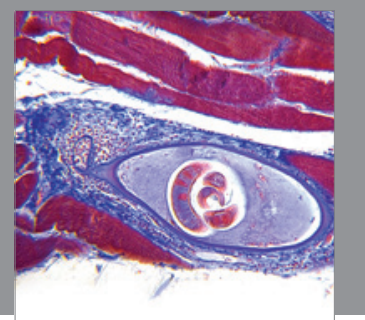

Gastroenterology

Research and Practice
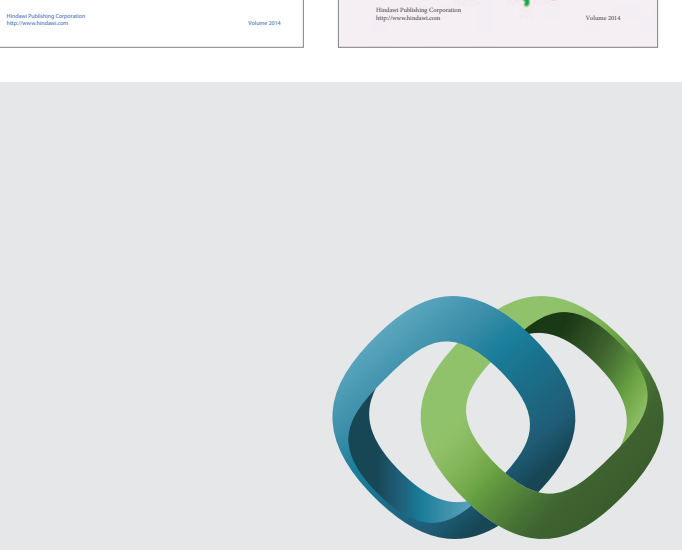

\section{Hindawi}

Submit your manuscripts at

http://www.hindawi.com
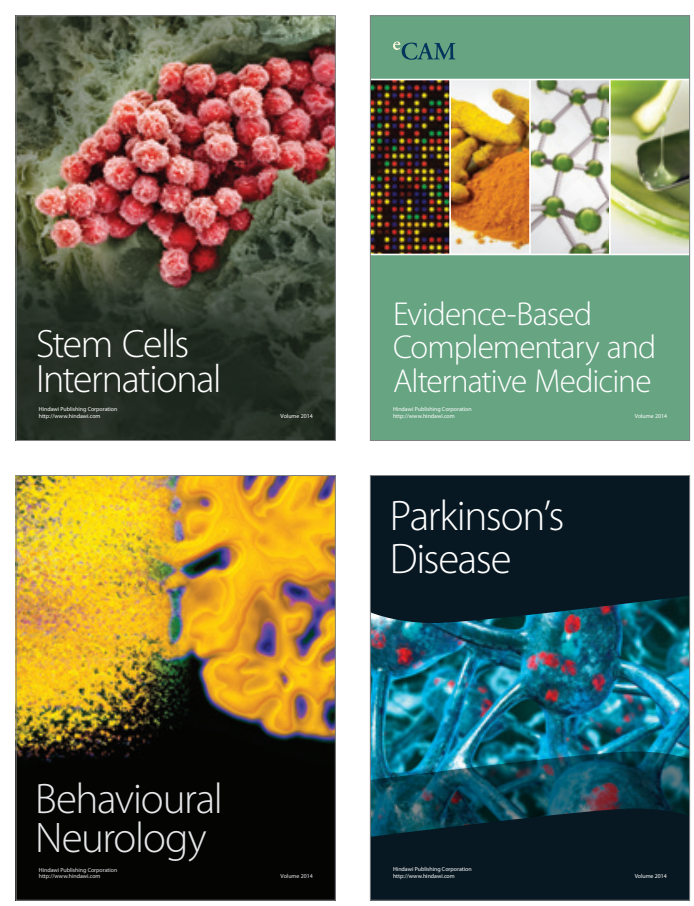

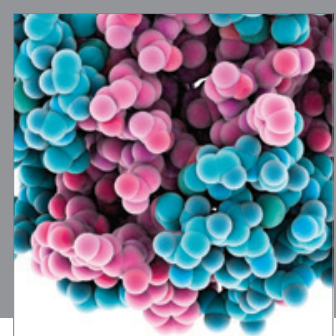

Journal of
Diabetes Research

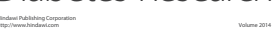

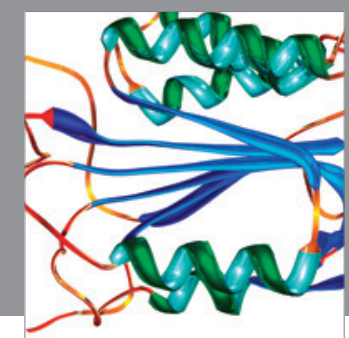

Disease Markers
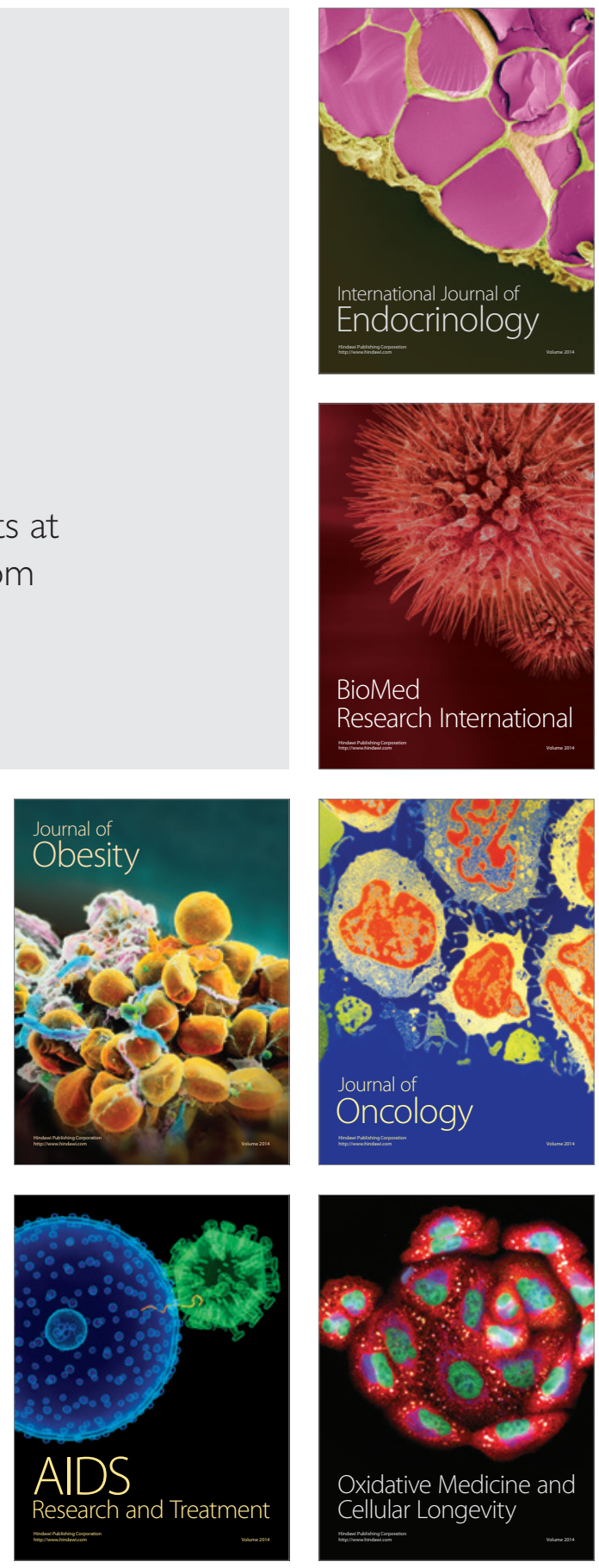